\title{
TAKE CARE
}

Ensuring the President "shall take Care that the Laws be faithfully executed"

\section{Executive Privilege(s) and the Testimony of James Comey}

Peter M. Shane // 6/9/17 // Commentary

Between the early speculation that the White House might try to block the testimony of former FBI Director James Comey to the post-testimony claim (https://www.usatoday.com/story/news/politics/2017/06/08/donald-trump-james-comey-hearing-marckasowitz/102588032/) by Trump lawyer Marc Kasowitz that Comey "admitted that he unilaterally and surreptitiously made unauthorized disclosures to the press of privileged communications with the president," it's been a big week for executive privilege aficionados. This primer might help sort out some sources of potential confusion. It comes with this caveat: So few disputes over executive privilege have been litigated that any interpretation must rely partly on general principles, as well as interpretation of past practice.

Not One, But Several. "Executive privilege" is best understood as an umbrella term for a series of privileges that somewhat differ in weight and scope. The idea uniting all of them is that the executive branch's viability as a functioning, co-equal branch of government depends, in a variety of contexts, on confidentiality. These privileges are really an entitlement, sometimes absolute, but most often "qualified," to resist the mandatory release of certain documents or compel certain kinds of testimony, whether in court or before Congress.

The narrowest, most absolute form of EP is "state secrets privilege." It covers information that ought not be released in order to protect the military and national security interests of the United States. The broadest, but arguably the least weighty is "deliberative privilege," which covers any information about discussions within the 
executive branch that preceded a final administrative decision of some sort. What Trump would have invoked is the presidential communication or presidential privacy privilege, which falls between the two in terms of weightiness. This was also the privilege at stake in United States V. Nixon (http://scholar.google.co.il/scholar case? case $=5132513257326080850 \& h l=e n \& a s \quad s d t=6 \& a s$ vis $=1 \&$ i $=$ scholarr\&sa $=X \& v e d=0 a h$ UKEwiO7NTWy $7 D U A h$ VDWXQKHWIfAYOQgAMIJigAMAA).

Balancing. In United States v. Nixon, the Supreme Court held that the presidential communication privilege is constitutionally based, but subject to balancing. A court, for example, could compel the disclosure of testimony or documents subject to the privilege if the need of the judicial branch for the information in order to fulfill its constitutional function in a particular context outweighs the President's general interest in the confidentiality of his communications. The executive branch has repeatedly cited Nixon over the decades for the proposition that the same analysis applies to congressional demands for information. Not surprisingly, it generally argues that the balance almost always favors executive secrecy.

In this case, it seems likely that the balance would go the other way. The executive branch has long conceded that withholding information probative of possible executive branch wrongdoing should not be withheld from Congress. Moreover, the presidential interest in the confidentiality of his conversations was likely weakened by his own public discussion of their content. The only way the competing interests could have been authoritatively adjudicated, however, would be if privilege had been claimed, Mr. Comey had decided to honor it, and the Senate or one of its committees had sued Mr. Comey to compel his testimony. (The executive branch would not have honored any congressional request to prosecute Mr. Comey for contempt had he declined to testify based on a Trump privilege claim.)

The Kasowitz Accusation. Given the applicable legal principles, Mr. Kasowitz would have been on more accurate ground if he stated that Mr. Comey had engaged in "unauthorized disclosures to the press of communications with the president that were presumptively privileged." Whether they were actually privileged would depend on the balancing analysis I described. In any event, even if the conversations were protected by presidential communication privilege, nothing in Mr. Comey's accounts of the conversations was classified. There is no law prohibiting someone in conversation with the President from revealing that conversation to third parties without the President's consent. We are in the realm of norms, not statutes.

Of course, one could well imagine that the unauthorized disclosure of a confidential presidential conversation would be a fireable offense if committed by any federal officer serving at the pleasure of the President. Unfortunately for the President, he had fired Mr. Comey before the unauthorized disclosure. There is no presidential privilege to fire the same person twice. 
Tags:

Congress Executive Branch Russian Interference

\section{Recently on Take Care}

\section{Versus Trump: Trump Wins One Versus Stormy.}

(/blog/versus-trump-trump-wins-one-versus-stormy.).

Charlie Gerstein, Joshua Matz // 10/18/18 // In-Depth Analysis

\section{A Progressive Yankee in John Roberts' Court}

(./blog/a-progressive-yankee-in-john-roberts-court).

Daniel Hemel // 10/17/18 // In-Depth Analysis

Advancing a Left-Liberal Jurisprudence

(.lblog/advancing-a-left-liberal-jurisprudence).

Jon D. Michaels // 10/16/18 // In-Depth Analysis

Raising Red Flags about Shelby_ounty.

(/blog/raising-red-flags-about-shelby-county).

Travis Crum // 10/15/18 // Commentary

Why Democrats Should Pack the Supreme Court

(//blog/why-democrats-should-pack-the-supreme-court).

Michael Klarman // 10/15/18 // In-Depth Analysis

Versus Trump: N.Y. Versus Wilbur Ross

(/blog/versus-trump-n-y-versus-wilbur-ross)

Charlie Gerstein, Jason Harrow // 10/11/18 // In-Depth Analysis

\section{Related Posts}

\section{Versus Trump: The Unique Manafort Plea}

(/blog/versus-trump-the-unique-manafort-plea)

\section{9/27/18 // Commentary}

On this week's episode of Versus Trump, Jason and Charlie talk about pardons, Double Jeopardy, forfeiture, and the Manafort guilty plea. They also weigh in on the Kavanaugh developments and what would happen if Rosenstein were fired. Listen now! 
Jason Harrow , Charlie Gerstein

Equal Citizens Civil Rights Corps

\section{Versus Trump: A Two-Level Versus Trump Case}

(/blog/versus-trump-a-two-level-versus-trump-case).

\section{8/30/18 // Commentary}

On this week's episode of Versus Trump, Jason and Charlie talk about a case that fits our podcast on two levels: it's a lawsuit against the Trump Administration about grand jury secrecy, and any decision could impact the Mueller investigation, which is the biggest Versus Trump case of them all. Listen now!

Charlie Gerstein , Jason Harrow

Civil Rights Corps Equal Citizens

\section{Versus Trump: Trump Versus ALJs?}

(lblog/versus-trump-trump-versus-aljs $)$

\section{8/2/18 // Commentary}

On this week's episode of Versus Trump, Jason and Easha discuss a new executive order and accompanying guidance by the Trump Administration that dramatically change the rules for hiring Administrative Law Judges (ALJs) across the entire federal government. Listen now!

\section{Jason Harrow , Easha Anand}

Equal Citizens San Francisco 


\section{(c) (i) (2)(2) (http://creativecommons.org/licenses/by-nc-sa/4.0/)}

This work is licensed under a Creative Commons Attribution-NonCommercial-ShareAlike 4.0 International License (http://creativecommons.org/licenses/by-nc-sa/4.0/). 